\title{
Dung beetle communities in coal mining areas in the process of recovery
}

\author{
Joana Zamprônio Bett ${ }^{1}$ \\ Patrícia Menegaz de Farias ${ }^{1,2 *}$ \\ Pedro Giovâni da Silva ${ }^{2}$ \\ Malva Isabel Medina Hernández ${ }^{2}$ \\ ${ }^{1}$ Laboratório de Entomologia \\ Centro de Desenvolvimento Tecnológico Amael Beethoven Villar Ferrim, \\ Departamento de Agronomia Universidade do Sul de Santa Catarina, CEP 88701-000, Tubarão - SC, Brasil \\ ${ }^{2}$ Laboratório de Ecologia Terrestre Animal, Programa de Pós-Graduação em Ecologia \\ Departamento de Ecologia e Zoologia, Universidade Federal de Santa Catarina \\ CEP 88040-900, Florianópolis - SC, Brasil \\ * Autor para correspondência \\ patricia.farias@unisul.br
}

Submetido em 04/03/2014

Aceito para publicação em 23/06/2014

\section{Resumo}

Escarabeíneos em áreas de mineração de carvão em processo de recuperação. Besouros escarabeíneos sensíveis a modificações ambientais podem apontar a recuperação de áreas degradadas. Este trabalho objetivou registrar e comparar as comunidades de Scarabaeinae em áreas com diferentes períodos de recuperação ambiental após serem usadas para mineração de carvão. O presente estudo foi realizado em duas áreas em recuperação (um e cinco anos) no município de Lauro Müller, Santa Catarina, e contou com 15 armadilhas de queda iscadas com fezes humanas em cada área. Em laboratório realizou-se a contagem, identificação e mensuração do tamanho corporal e biomassa dos espécimes capturados. Verificou-se a suficiência amostral e as variáveis de ambas as áreas foram comparadas através de teste $t$. As espécies registradas foram: Canthon aff. chalybaeus, Canthon angularis, Canthon rutilans cyanescens, Deltochilum multicolor, Dichotomius sericeus, Eurysternus parallelus e Ontherus sulcator. O número total de indivíduos capturados foi de 35 , sendo três na área de um ano em recuperação e 32 na de cinco anos; a espécie mais abundante foi C. rutilans cyanescens (40,6\%). Todas as espécies estiveram presentes na área de cinco anos, mas somente $C$. aff. chalybaeus e $D$. multicolor na área de um ano. O tamanho médio dos indivíduos amostrados na área de um ano de recuperação foi de $11,03 \mathrm{~mm} \mathrm{e}$ a biomassa $0,051 \mathrm{~g}$, enquanto que na área com cinco anos de recuperação o tamanho médio e a biomassa dos besouros escarabeíneos amostrados foi de $12,25 \mathrm{~mm}$ e $0,093 \mathrm{~g}$, respectivamente.

Palavras-chave: Carvão mineral; Ecologia; Indicadores; Recuperação ambiental; Scarabaeinae

\section{Abstract}

Dung beetles that are sensitive to environmental alterations may be used as indicator species to mark the recovery of degraded areas. This work aimed at registering and comparing the communities of Scarabaeinae located in areas with different periods of environmental recovery after being used for coal mining. This study 
was developed in Lauro Müller, Santa Catarina, and consisted of two areas in the process of recovery, one for one year and one for five years. Fifteen pitfall traps baited with human feces were placed in each area in order to attract the dung beetles. The counting, identification and measurement of body size and biomass of the specimens captured were carried out in the laboratory. Sampling sufficiency was verified and variables from both areas were compared using a $t$ test. The recorded species were Canthon aff. chalybaeus, Canthon angularis, Canthon rutilans cyanescens, Deltochilum multicolor, Dichotomius sericeus, Eurysternus parallelus and Ontherus sulcator. A total of 35 individuals were captured, three in the one-year recovery area and 32 in the area under recovery for five years, $C$. rutilans cyanescens being the most abundant species $(40.6 \%)$. All species collected were found in the five-years recovery area, whereas only $C$. aff. chalybaeus and D. multicolor were found in the one-year recovery area. Individuals sampled in the area with one year of recovery had an average size of 11.03 $\mathrm{mm}$ and average biomass of $0.051 \mathrm{~g}$, whereas in the five-years recovery area the average size and the biomass of the dung beetles sampled was $12.25 \mathrm{~mm}$ and $0.093 \mathrm{~g}$, respectively.

Key words: Indicators; Ecology; Environmental recovery; Mineral coal; Scarabaeinae

The mining process is widely acknowledged as a source of environmental problems (SILVA, 2011), as mining activities often result in the elimination of vegetation and the interruption of gene flow via fragmentation of habitats, causing death or extinction of fauna (MECHI; SANCHEZ, 2010). The process of induced environmental recovery aims to accelerate the reestablishment of habitat by improving abiotic conditions in degraded areas in accordance with future use (PEREIRA; RODRIGUES, 2012). Topographic and landscape re-composition, as well as soil reconstruction are actions that seek to make the environment favorable for the development of animal and plant species (COSTA; ZOCCHE, 2009). The presence of indicator organisms during the recovery process may help the monitoring process by elucidating mechanisms of environmental re-composition (CAMPOS et al., 2012). Such organisms have life history traits intrinsically related to their habitat in such a way that any alteration can influence population dynamics (PAOLETTI, 1999). Such species are regarded as indicators of environmental quality, for they reflect the ecological integrity of the ecosystems and thus may be used as a proxy to measure the degradation levels of sites in recovery (LUTINSKI; GARCIA, 2005).

Dung beetles (Coleoptera: Scarabaeidae: Scarabaeinae) were indicated by Halffter and Favila (1993) as important bioindicators because they respond to environmental variation. It is frequently observed that the most diverse communities with species of greater body size are located in preserved forest areas, and that degraded areas show a decrease in dung beetle abundance, species richness and body size (GARDNER et al., 2008).

This group performs several ecosystem services (reviewed by NICHOLS et al., 2008), operating in ecological processes such as increasing the rate of nutrient cycling through the allocation of food resources, the opening of galleries that facilitate water and air circulation in soil (MITTAL, 1993), breaking of the life cycle of some parasites of vertebrates (RIDSDILLSMITH; HAYLES, 1990), and the secondary dispersion of seeds, which may influence forest regeneration (ANDRESEN, 2002).

Studies that analyze dung beetle communities in areas recovering from coal mining practices show that older recovered areas allow greater species presence, which contributes to the increase of ecosystem services (HERNÁNDEZ et al., unpublished data). As a contribution to the monitoring of environmental quality in altered landscapes, this work focused on registering and comparing the communities of Scarabaeinae located in areas with different periods of environmental recovery after being used for coal mining.

The study was carried out in Lauro Müller, Santa Catarina, Brazil between January and February 2013, a period of great dung beetle abundance in subtropical regions (HERNÁNDEZ; VAZ-DE-MELLO, 2009; SILVA et al., 2013). The annual relative humidity of the study region varies between $80 \%$ and $85 \%$, and the average annual rainfall is between 1,400 and $1,600 \mathrm{~mm}$. The average annual temperature is between $16^{\circ} \mathrm{C}$ and 
$18^{\circ} \mathrm{C}$. The predominant climate is humid mesothermal with hot winter (Cfa) (EPAGRI/CIRAM, 2010).

Two areas with different periods of recovery from mining were sampled: the first one $\left(28^{\circ} 19^{\prime} \mathrm{S}, 49^{\circ} 26^{\prime} \mathrm{W}\right)$ with an area of $0.032 \mathrm{~km}^{2}$, has been in recovery for roughly one year and is characterized as implanted pasture with fragments of secondary forest. It is delimited east by a road, and is surrounded by farms with native pasture used for extensive cattle breeding in the north, south and west. The second area (28 $\left.22^{\prime} \mathrm{S}, 49^{\circ} 27^{\prime} \mathrm{W}\right)$, with an area of $0.021 \mathrm{~km}^{2}$, has been in recovery for five years and is covered by implanted pasture. It is delimited north and west by a long area of preserved forest; in the south, a reforested area with eucalyptus; and in the east, a native pasture used for cattle breeding. Fifteen baited pitfall traps each $50 \mathrm{~m}$ apart were placed in each area. Traps contained water with a neutral detergent to break the surface tension and prevent the insects from escaping. The rain shields of traps were baited with human feces $(20 \mathrm{~g})$ to attract the individuals; this is one the most employed and efficient methods for the capture of the majority of the species in this group (LOBO et al., 1988). Traps remained in the field for 48 hours, after which captured insects were collected and transferred to receptacles containing alcohol (70\%). Individuals were oven-dried at $60^{\circ} \mathrm{C}$ for 48 hours, and the counting, identification, measurement of the body size and weight were carried out in the laboratory. The specimens are in the entomological collection at the entomology laboratory of Universidade do Sul de Santa Catarina.

A total of 35 individuals from seven species of Scarabaeinae were collected $91,4 \%(n=32)$ of the total individuals were captured in the area recovering for five years, whereas only $8,6 \%(n=3)$ of the total were captured in the area recovering for one year. Seven species were recorded in five-year recovery area: Canthon aff. chalybaeus Blanchard $(\mathrm{n}=6)$, Canthon angularis Harold $(\mathrm{n}=1)$, Canthon rutilans cyanescens Harold ( $\mathrm{n}=13)$, Deltochilum multicolor Balthasar ( $\mathrm{n}=$ 4) (tribe Deltochilini), Dichotomius sericeus (Harold) $(\mathrm{n}=4)$, Ontherus sulcator (Fabricius) $(\mathrm{n}=3)$ (tribe Coprini) and Eurysternus parallelus Castelnau $(\mathrm{n}=1)$ (tribe Oniticellini). Only two species were recorded in the one-year recovery area: $C$. aff. chalybaeus $(\mathrm{n}=2)$ and
D. multicolor $(\mathrm{n}=1)$. The species sampled are common in areas of Atlantic Forest in Santa Catarina (CAMPOS; HERNÁNDEZ, 2013).

Sampling sufficiency was corroborated by the Chao 1 estimator, which estimated $100 \%$ of the richness observed in the area of five years $(7 \pm 0.25)$ and in the area of one year $(2 \pm 0.17)$. T-test showed that the five-year recovery area showed greater average species richness per trap $(1.6 \pm 0.38)$ than did the one-year area $(0.2 \pm 0.01)(t=1.97 ; \mathrm{df}=1 ; \mathrm{p}=0.034)$, a result in agreement with Davis et al. (2003) and Hernández et al. (unpublished data), both of which indicate higher species richness in areas allowed to recover from mining for longer time periods. However, Audino et al. (2014) emphasize that dung beetle assemblages are severely impoverished in restored sites, and that even after 18 years the communities remain poor in species richness.

Environmental structure is an important aspect of the organization of dung beetle communities (HERNÁNDEZ; VAZ-DE-MELLO, 2009; CAMPOS; HERNÁNDEZ, 2013). However, a confounding factor in the explanation for the increase in richness is the proximity to areas with more preserved habitats, which may act as a source area or species pool. However, it is known that the proximity to more adequate environments does not determine species richness in dung beetles, as traps placed only 15 meters from forests are not effective for their capture (KLEIN, 1989).

Although the average size and biomass of individuals sampled in the area of one year under recovery $(11.03 \mathrm{~mm}$ and $0.051 \mathrm{~g})$ were similar to that of the area of five years $(12.25 \mathrm{~mm}$ and $0.093 \mathrm{~g})$, the total biomass was more than 15 times greater in the area of five years $(2.47 \mathrm{~g})$ than in the other area $(0.15 \mathrm{~g})$. Gardner et al. (2008) showed that within all genera of Scarabaeinae, there is a decrease in larger species in degraded areas in Brazilian Amazonia. According to Barragán et al. (2011), the functional richness may also decrease with increasing degree of the environmental alteration, which is directly related to the ecosystem services performed. Therefore, our results suggest that the period of recovery and the resulting increase in the structural complexity of the environment are the aspects that most contributed to the increase of abundance, richness and biomass of dung 
beetles in the area recovered for a longer time period, confirming that dung beetles have a strong potential to be used as ecological indicators in areas in the process of environmental recovery.

\section{References}

ANDRESEN, E. Dung beetles in a Central Amazonian rainforest and in their ecological role as secondary seed dispersers. Ecological Entomology, London, v. 27, p. 257-270, 2002.

AUDINO, L. D.; LOUZADA, J.; COMITA, L. Dung beetles as indicators of tropical forest restoration success: Is it possible to recover species and functional diversity? Biological Conservation, Boston, v. 169, p. 248-257, 2014.

BARRAGÁN, F.; MORENO, C. E.; ESCOBAR, F.; HALFFTER, G.; NAVARRETE, D. Negative impacts of human land use on dung beetle functional diversity. PLoS ONE, San Francisco, v. 6, n. 3, 2011.

CAMPOS, R. C.; HERNÁNDEZ, M. I. M. Dung beetle assemblages (Coleoptera, Scarabaeinae) in Atlantic forest fragments in southern Brazil. Revista Brasileira de Entomologia, Curitiba, v. 57, n. 1, p. 47-54, 2013.

CAMPOS, W. H.; NETO, A. M.; PEIXOTO, H. J. C.; GODINHO, L. B.; SILVA, E. Contribuição da fauna silvestre em projetos de restauração ecológica no Brasil. Pesquisa Florestal Brasileira, Colombo, v. 32, n. 72, p. 429-440, 2012.

COSTA, S.; ZOCCHE, J. J. Fertilidade de solos construídos em áreas de mineração de carvão na região Sul de Santa Catarina. Revista Árvore, Viçosa, v. 33, n. 4, p. 665-674, 2009.

DAVIS, L. V.; VAN ARDE, R. J.; SCHOLTZ, C. H.; DELPORT, J. H. Convergence between dung beetle assemblages of a postmining vegetational chronosequence and unmined dune forest. Restoration Ecology, Crawley, v. 11, n. 1, p. 29-42, 2003.

EPAGRI/CIRAM - EMPRESA DE PESQUISAS AGROPECUÁRIA E DE EXTENSÃO RURAL DE SANTA CATARINA. Dados e informações bibliográficas da Unidade de Planejamento Regional Litoral Sul Catarinense - UPR 8. Florianópolis: EPAGRI, 2010. 300 p.

GARDNER, T. A.; HERNÁNDEZ, M. I. M.; BARLOW, J.; PERES, C. A. Understanding the biodiversity consequences of habitat change: the value of secondary and plantation forests for Neotropical dung beetles. Journal of Applied Ecology, London, v. 45, p. 883-893, 2008.
HALFFTER, G.; FAVILA, M. E. The Scarabaeinae (Insecta: Coleoptera) an animal group for analyzing, inventorying and monitoring biodiversity in tropical rainforest and modified landscapes. Biology International, Paris, v. 27, p. 15-21, 1993.

HERNÁNDEZ, M. I. M.; VAZ-DE-MELLO, F. Z. Seasonal and spatial species richness variation of dung beetle (Coleoptera, Scarabaeidae s. str.) in the Atlantic Forest of southeastern Brazil. Revista Brasileira de Entomologia, Curitiba, v. 53, n. 4, p. 607613, 2009.

KLEIN, B. C. Effects of forest fragmentation on dung and carrion beetle communities in Central Amazonia. Ecology, Washington, v. 70, n. 6, p. 1715-1725, 1989.

LOBO, J. M.; MARTÍN-PIERA, F.; VEIGA, C. M. Las trampas pitfall con sebo, sus posibilidades en el estudio de las comunidades coprófagas de Scarabaeoidea (Col.). I. Características determinantes de su capacidad de captura. Revue d'Écologie et de Biologie du Sol, Paris, v. 25, n. 1, p. 77-100, 1988.

LUTINSKI, J. A.; GARCIA, F. R. M. Análise faunística de Formicidae (Hymenoptera: Apocrita) em ecossistema degradado no município de Chapecó, Santa Catarina. Biotemas, Florianópolis, v. 18, n. 2, p. 73-86, 2005.

MECHI, A.; SANCHES, D. L. Impactos ambientais da mineração no estado de São Paulo. Estudos Avançados, São Paulo, v. 24, n. 68, p. 209-220, 2010.

MITTAL, I. Natural manuring and soil conditioning by dung beetles. Tropical Ecology, Varanasi, v. 34, p. 150-159, 1993.

NICHOLS, E.; SPECTOR, S.; LOUZADA, J.; LARSEN, T.; AMEZQUITA, S.; FAVILA, M. E. Ecological functions and ecosystem services provided by Scarabaeinae dung beetles. Biological Conservation, Washington, v. 141, p. 1461-1474, 2008.

PAOLETTI, M. G. Using bioindicators based on biodiversity to assess landscape sustainability. Agriculture, Ecosystems \& Environment, Amsterdan, v. 74, p. 1-18, 1999.

PEREIRA, J. S.; RODRIGUES, S. C. Crescimento de espécies arbóreas utilizadas na recuperação de área degradada. Caminhos de Geografia, Uberlândia, v. 13, n. 41, p. 102-110, 2012.

RIDSDILL-SMITH, T. J.; HAYLES, L. Stages of bush fly, Musca vetustissima (Diptera: Muscidae), killed by scarabaeine dung beetles (Coleoptera: Scarabaeidae) in unfavourable cattle dung. Bulletin of Entomological Research, Cambridge, v. 80, p. 473478, 1990.

SILVA, A. S. Mineração e áreas de preservação permanentes (APPs) em Santo Antônio de Pádua - RJ. Sociedade e Natureza, Uberlândia, v. 23, n. 2, p. 173-185, 2011.

SILVA, P. G.; VAZ-DE-MELLO, F. Z.; DI MARE, R. A. Diversity and seasonality of Scarabaeinae (Coleoptera: Scarabaeidae) in forest fragments in Santa Maria, Rio Grande do Sul, Brazil. Anais da Academia Brasileira de Ciências, Rio de Janeiro, v. 85, n. 2, p. 679-697, 2013. 